\author{
KRYSTYNA STEFAŃSKA ${ }^{1}$
}

\title{
Miejsce rodzinnego gospodarstwa rolnego w obrocie rolnym (zagadnienia wybrane)
}

1. Instytucji rodzinnego gospodarstwa rolnego poświęcono już w literaturze oraz orzecznictwie wiele uwagi. ${ }^{2}$ Ciągłą aktualność problematyki wyznacza zwłaszcza przepis art. 23 konstytucji, który określił gospodarstwo rodzinne jako podstawę ustroju rolnego państwa, ${ }^{3}$ wskazując w ten sposób kierunek kształtowania przyszłego ustawodawstwa. ${ }^{4}$ Przyjmowane w tym zakresie ustawodawstwo nawiązuje do prawnego pojęcia gospodarstwa rodzinnego, podejmuje próbę określenia modelu tego gospodarstwa oraz jest wyrazem określenia w oparciu o koncepcję gospodarstwa rodzinnego celów ustrojowych naszego rolnictwa. Analiza przyjmowanych rozwiązań prawnych dotyczących zwłaszcza przekształceń strukturalnych w rolnictwie uzasadnia pytanie, na ile rodzinne gospodarstwo rolne wskazane w konstytucji jako podstawa ustroju rolnego traktowane jest jako określona wartość, która miałaby być przedmiotem ochrony prawnej, a na ile jako instrument służący realizacji innych celów.

Przedmiotem uwagi w tym zakresie będzie ta część regulacji prawnej, która dotyczy obrotu rolnego. Jest to ta dziedzina stosunków społecznych, do których szczególnie często nawiązuje się przy regulowaniu przekształceń ustrojowych naszego rolnictwa i jak potwierdza stan przyjmowanego w tym zakresie ustawodawstwa, nawiązuje ono w szerokim zakresie do instytucji rodzinnego gospodarstwa rolnego. Poszukiwanie odpowiedzi na postawione pytanie, na ile rodzinne gospodarstwo rolne jest wartością prawnie chronioną, a na ile instrumentem służącym realizacji innych celów, uzasadnia zwrócenie uwagi zwłaszcza na dwa aspekty wynikające z treści art. 23 konstytucji.

$1 \quad$ Uniwersytet Łódzki.

2 Por. np. A.Oleszko, Uznanie rodzinnego gospodarstwa rolnego jako konstytucyjnej podstawy polskiego ustroju rolnego (uwagi do Konstytucji RP z dnia 2 kwietnia 1997), „Rejent” 1997, nr 5, s. 79 i n.; A. Lichorowicz, Konstytucyjne podstawy ustroju rolnego RP (w świetle art. 23 Konstytucji, „Studia luridica Agraria” 2000, t. I, s. 25-45; tenże, Regulacja obrotu gruntami rolnymi według ustawy z 11.IV.2003 r. o kształtowaniu ustroju rolnego na tle ustawodawstwa agrarnego Europy Zachodniej, „Studia luridica Agraria” 2005, t. 4, s. 9 i n.

4 O roli konstytucji w rozwoju prawa rolnego por. R. Budzinowski, Problemy ogólne prawa rolnego. Przemiany podstaw legislacyjnych i koncepcji doktrynalnych, Poznań 2008, s. 60 i n. Autor zaznacza m.in., że społeczną funkcją konstytucji nie jest jedynie opis istniejącej rzeczywistości, ale również kształtowanie tej rzeczywistości w przyszłości. 
2. Ich wyraźne sformułowanie ułatwi przypomnienie znaczenia pojęcia „ustrój rolny”, w którego kontekście użyto w konstytucji pojęcia „gospodarstwo rodzinne”. Zgodnie z przyjętym rozumieniem „ustrój rolny” to układ stosunków własnościowych i form organizacji produkcji w rolnictwie, jak również form organizacyjnych rynku rolnego". ${ }^{5}$ Gospodarstwo rodzinne, w związku z treścią art. 23 konstytucji i znaczeniem użytego w tym przepisie pojęcia „ustrój rolny”, ma więc po pierwsze: spełniać podstawową rolę w budowaniu stosunków własnościowych w rolnictwie, a po drugie: wskazany model gospodarstwa rodzinnego ma zajmować szczególne miejsce wśród innych form gospodarowania w rolnictwie. Gospodarstwo rodzinne jest $\mathrm{w}$ świetle konstytucji wartością, która ma być prawnie chroniona. Bardzo wyraźnie wskazał na tę rolę art. 23 konstytucji Trybunał Konstytucyjny w wyroku z dnia 31.01.2001 r., ${ }^{6}$ pisząc m.in., że ,przepis ten formułuje koncepcję gospodarstwa rodzinnego jako wytyczną dla organów władzy państwowej” oraz że „ustawodawca w granicach przysługującej mu swobody regulowania dziedziczenia - odwoła się do koncepcji rodzinnego gospodarstwa rolnego jako wartości konstytucyjnej i realizując ją, potraktuje gospodarstwo rolne jako szczególny przedmiot dziedziczenia, a więc podda go w określonym zakresie pewnym odrębnym regulacjom". Podobny pogląd TK wyraził w wyroku z dnia 5.09.2007 r. ${ }^{7}$ Równocześnie warto odnotować ten fragment uzasadnienia obu cytowanych wyroków TK, w których TK stwierdza m.in, że „gospodarstwo rodzinne nie jest celem samym w sobie" oraz że ,powinno ono stanowić efektywną formę gospodarowania, pozwalającą prowadzić produkcję rolną w celu nie tylko zapewnienia „godziwego" utrzymania rodzinom rolniczym, ale także najpełniejszego zaspokojenia potrzeb społeczeństwa”. TK wskazał więc na dwa aspekty miejsca rodzinnego gospodarstwa rolnego w ustawodawstwie. Po pierwsze, odnotował jego pozycję ustrojową, po drugie, zauważył rolę gospodarstwa rolnego jako jednostki produkcyjnej, pisząc m.in., że „prowadzenie gospodarstwa rolnego może być traktowane jako szczególny rodzaj działalności gospodarczej, a samo gospodarstwo rolne uznawane być może za rodzaj przedsiębiorstwa". Dlatego też, jak pisze TK w uzasadnieniu cytowanych tu wyroków, można założyć, że władze publiczne mają obowiązek podejmowania działań, aby prowadzenie gospodarstwa rolnego było „produktywną” formą gospodarowania.

W świetle art. 23 konstytucji rodzinne gospodarstwo rolne jest wartością prawnie chronioną ${ }^{8}$ Przepis ten wyznacza podstawowy, ustrojowy model gospodarstwa rolnego, ale gospodarstwo to jest równocześnie jednostką produkcji rolnej prowadzącą działalność gospodarczą, dla której prowadzenia powinny być spełnione określone przesłanki przedmiotowe i podmiotowe i która także w tej płaszczyźnie po- 
winna podlegać ochronie. Zwraca na to uwagę P. Czechowski, który komentując stanowisko TK w cytowanym wyroku z dnia 31.01.2001 r. stwierdził m.in, że zasada ochrony gospodarstwa rolnego w nowych warunkach ustrojowych została utrzymana w przepisach konstytucji (art. 23), ale została osłabiona w wyniku wyroku TK na rzecz powszechności dostępu spadkobierców niebędących rolnikami do możliwości ubiegania się o dojście do masy spadkowej na zasadach ogólnych. ${ }^{9}$ Równocześnie P. Czechowski odnotowuje, że oddziaływanie prawa w sferze ochrony gospodarstwa rolnego jako warsztatu pracy nadal obowiązuje. Jak wynika z cytowanych wyroków, TK wskazuje nawet na konieczność zwiększania stopnia tej ochrony, pisząc np., że „zasada równej ochrony prawa dziedziczenia nie ma charakteru absolutnego i nie wyklucza możliwości ograniczenia wysokości spłat należnych od spadkobiercy uzyskującego gospodarstwo rolne w wyniku działu spadku, ani rozłożenia w czasie ich płatności, jeżeli uzasadnione jest to potrzebą ochrony rodzinnego charakteru danego gospodarstwa albo zapewnienia prawidłowego i racjonalnego gospodarowania". ${ }^{10}$

Wskazane przez TK dwie płaszczyzny interpretacji art. 23 konstytucji, a mianowicie: zaznaczenie konieczności ochrony rodzinnego gospodarstwa rolnego jako wartości konstytucyjnej oraz jako jednostki produkcji rolnej, w której prowadzona jest działalność gospodarcza, znajduje także swój wyraz w zaproponowanym przez A. Lichorowicza katalogu zasad prawa rolnego. Spośród tych zasad autor wyróżnia m.in.: 1) zasadę ochrony trwałości warsztatu pracy producenta rolnego, a w obrębie tej zasady pewne jej aspekty, jak np. a) zasadę szczególnej ochrony interesów osób faktycznie prowadzących produkcję rolną wobec osób niebędących producentami rolnymi, czy b) zasadę pozytywnego oddziaływania na strukturę gruntową gospodarstw rolnych w celu jej modernizacji i zapewnienia gospodarstwom samowystarczalności ekonomicznej. Jako kolejną zasadę autor wskazuje na 2) konstytucyjną zasadę szczególnej ochrony rodzinnego charakteru gospodarstw jako podstawy ustroju rolnego Polski (art. 23 konstytucji). ${ }^{11}$

Patrząc na zaprezentowany przez autora pogląd na temat zasad prawa rolnego uzasadniona wydaje się konstatacja, że zakres dwóch pierwszych, cytowanych tu zasad wskazuje także na te regulacje prawne, które odnoszą się do gospodarstw rodzinnych. Gospodarstwa te są przecież także miejscem pracy producenta rolnego, chociaż nie tylko te gospodarstwa znajdują się w tej grupie. W przypadku wskazywanych tu zasad akcentuje się przede wszystkim społeczne i gospodarcze przesłanki oddziaływania określonych regulacji prawnych. Natomiast wskazanie jako odrębnej, konstytucyjnej zasady - szczególnej ochrony rodzinnego charakteru go-

P. Czechowski, Zasady prawa rolnego - stabilizacja czy ewolucja?, „Studia luridica Agraria” 2011, t. 9, s. 110. Bliżej na ten temat K .Stefańska, Gospodarstwo rodzinne jako element ustroju rolnego, „Studia luridica Agraria” 2002, t. 3, s. 174 i n.

A. Lichorowicz, Miejsce prawa rolnego w polskim systemie prawa, (w:) Prawo rolne, pod red. A. Stelmachowskiego, Warszawa 2009, s. 30. 
spodarstw, jako podstawy ustroju rolnego Polski, zwraca naszą uwagę na znaczenie tych gospodarstw dla kształtowania m.in. stosunków własnościowych w rolnictwie oraz ich miejsca wśród innych form gospodarowania w rolnictwie, zgodnie z przyjmowanym znaczeniem pojęcia ,ustrój rolny". ${ }^{2}$ Dalsze rozważania będą miały na celu poszukiwanie odpowiedzi, na ile obowiązujące ustawodawstwo odwołujące się do rodzinnych gospodarstw rolnych daje wyraz założeniom wynikającym z konstytucji oraz $\mathrm{w}$ jakim zakresie odpowiada doktrynalnym koncepcjom dotyczących zasad prawa rolnego.

3. Punktem wyjścia dla dalszej analizy na ten temat będzie przypomnienie normatywnego określenia pojęcia gospodarstwa rodzinnego zawartego $\mathrm{w}$ ustawie $\mathrm{z}$ dnia 11.04.2003 r. o kształtowaniu ustroju rolnego. ${ }^{13}$

Zgodnie z treścią art. 5 ust. 1 u.k.u.r. za gospodarstwo rodzinne uważa się gospodarstwo rolne: 1) prowadzone przez rolnika indywidualnego oraz 2) w którym łączna powierzchnia użytków rolnych jest nie większa niż 300 ha. Dalsze rozwinięcie treści tych dwóch przesłanek znajdujemy w kolejnych przepisach cyt. ustawy, wśród których kluczowe znaczenie ma treść art. 6, który definiuje pojęcie rolnika indywidualnego. Obszerne omówienie treści wskazanych tu przepisów ustawy zawarte są zwłaszcza w opracowaniach A. Lichorowicza ${ }^{14}$ i Z. Truszkiewicza. ${ }^{15} \mathrm{Na}-$ leży odnotować, że patrząc na aktualne brzmienie wskazanych przepisów u.k.u.r., zauważamy uwzględnienie przez ustawodawcę szeregu uwag krytycznych zgłaszanych wcześniej w opracowaniach cytowanych autorów. Zgodnie z obecną treścią art.

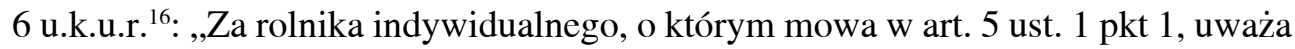
się osobę fizyczną będącą właścicielem, użytkownikiem wieczystym, samoistnym posiadaczem lub dzierżawcą nieruchomości rolnych, których łączna powierzchnia użytków rolnych nie przekracza 300 ha, posiadającą kwalifikacje rolnicze oraz co najmniej od 5 lat zamieszkałą w gminie, na obszarze której jest położona jedna z nieruchomości rolnych wchodzących w skład gospodarstwa rolnego i prowadzącą przez ten okres osobiście to gospodarstwo". W dalszej części przepis art. 6 ust. 2 i 3 określa sposób rozumienia pojęcia osobistego prowadzenia gospodarstwa rolnego wskazując, że chodzi w tym przypadku o pracę w gospodarstwie rolnym oraz podejmowanie wszelkich decyzji dotyczących prowadzenia działalności rolniczej w tym gospodarstwie (art. 6 ust. 2 pkt 1), zaś kwalifikacje rolnicze wynikają z teoretycznego wykształcenia rolniczego lub stażu pracy w rolnictwie (art. 6 ust. 2 pkt 2). Jak

$\mathrm{Na}$ zasadę ochrony gospodarstwa rolnego jako warsztatu pracy rolnika oraz ochrony innych form gospodarowania ziemią wskazuje także P. Czechowski, Zasady prawa rolnego..., op. cit., s. 113.

Tekst jedn. Dz.U. z 2012 r. poz. 803, cyt. dalej jako „u.k.u.r.”

14 A. Lichorowicz, Instrumenty oddziaływania na strukturę gruntową Polski w ustawie z dnia 11 kwietnia 2003 r. o kształtowaniu ustroju rolnego, „Kwartalnik Prawa Prywatnego” 2004, z. 2, s. 387 i n.

15 Z. Truszkiewicz, Przeniesienie własności nieruchomości rolnej w świetle ustawy o kształtowaniu ustroju rolnego (część II), „Rejent” 2003, nr 11, s. 113 i n.

16 W brzmieniu ustawy z dnia 16.09.2011 r. o zmianie ustawy o gospodarowaniu nieruchomościami rolnymi Skarbu Państwa oraz o zmianie niektórych innych ustaw (Dz.U. Nr 233, poz. 1382). 
wynika $\mathrm{z}$ zestawienia obecnego brzmienia przepisu art. 6 ust. 1 i 2 z jego dawnym odpowiednikiem (u.k.u.r. w jej pierwotnym brzmieniu), w zakres pojęcia „osobiste prowadzenie gospodarstwa rolnego" włączono także przesłankę pracy w gospodarstwie, zaś w przypadku kwalifikacji nie ma już dawnego rozwiązania pozwalającego uważać za rolnika indywidualnego także osobę, która uzyskała wykształcenie co najmniej zasadnicze lub wykształcenie średnie lub wyższe - niekoniecznie więc rolnicze. Należy także zauważyć, że na przyjęte zmiany u.k.u.r. w istotny sposób wpłynęła praktyka stosowania omawianych przepisów. Jak wskazywano, Agencja Nieruchomości Rolnych ${ }^{17}$ występowała już w 2003 roku do ministra Rolnictwa i Rozwoju Wsi z propozycją zajęcia stanowiska $\mathrm{w}$ sprawie np. rozumienia pojęcia „osobistego prowadzenia" gospodarstwa, wskazując najistotniejsze przesłanki świadczące o prowadzeniu gospodarstwa rolnego (praca w gospodarstwie, osobiste składanie oświadczeń w sprawach związanych z funkcjonowaniem gospodarstwa np. umowy z dostawcami, odbiorcami, bankami, ubezpieczycielami, zamieszkiwanie na terenie gospodarstwa lub w miejscu umożliwiającym pracę w gospodarstwie). Odnotowywano, że osoby nie będące faktycznie rolnikami, uzyskiwały od stosownych organów poświadczenia oświadczeń o osobistym prowadzeniu gospodarstwa rolnego, co umożliwiało im np. uczestnictwo w przetargach ograniczonych..$^{18}$ Doświadczenia stosowania u.k.u.r. w praktyce wpłynęły także na zmianę przyjętego w ustawie kryterium obszarowego nieruchomości rolnej w przypadku, gdy ANR może wykonać prawo pierwokupu w razie sprzedaży takiej nieruchomości. Obecnie przyjęto kryterium 5 ha stanowiąc, że Agencji przysługuje prawo pierwokupu, gdy przedmiotem sprzedaży jest nieruchomość rolna o powierzchni nie mniejszej niż 5 ha (art. 3 ust. 4 u.k.u.r.), oraz że Agencja może złożyć oświadczenie o nabyciu nieruchomości rolnej, jeżeli przeniesienie własności nieruchomości rolnej o powierzchni nie mniejszej niż 5 ha, następuje w wyniku zawarcia umowy innej niż umowa sprzedaży (art. 4 ust. 1). ${ }^{19}$ Wskazywano, że w praktyce Agencja rozpatrywała możliwość skorzystania z przysługujących jej uprawnień w odniesieniu do nieruchomości faktycznie nierolnych bądź o znikomej powierzchni, których rola w realizacji celów ustawy, a zwłaszcza tworzenia i powiększania gospodarstw rodzinnych, była znikoma. Dlatego też postulowano podniesienie kryterium obszarowego dla tych nieruchomości do obszaru powyżej 1 ha. ${ }^{20}$ Ustawodawca, jak wskazuje cyt. nowelizacja u.k.u.r. z dnia 6.05.2010 r., podniósł tę normę do powierzchni większej niż 5 ha. Jest to rozwiązanie właściwe. Daje ono Agencji możliwość skuteczniejszej realizacji zadania wynikającego dla Agencji z ustawy z dnia 19.10.1991 r., ${ }^{21}$ a określonego

Cyt. dalej jako „ANR”.

Por. T. Ciodyk, T. Zagórski i P. Iwaszkiewicz, Ustawa o kształtowaniu ustroju rolnego w praktyce, „Studia luridica Agraria" 2005, t. 4, s. 149.

Por. ustawę z dnia 6.05 .2010 r. o zmianie ustawy o kształtowaniu ustroju rolnego (Dz.U. Nr 110, poz. 725). T. Ciodyk, T. Zagórski, P. Iwaszkiewicz, Ustawa..., op. cit., s. 147.

Ustawa z dnia 19.10.1991 r. o gospodarowaniu nieruchomościami rolnymi Skarbu Państwa (Dz.U. z 2007, Nr 231, poz. 1700 z późn. zm., cyt. dalej jako „ustawa z dnia 19.10.1991 r.” 
jako „tworzenie oraz poprawa struktury obszarowej gospodarstw rodzinnych” (art. 6 ust. 1 pkt 1). Taki wniosek wydaje się być logiczny w kontekście omawianej u.k.u.r. Przedmiotem zainteresowania ANR są bowiem nieruchomości rolne, których obszar wyznacza bardziej skuteczną rolę w przekształceniach strukturalnych rolnictwa.

4. Równocześnie jednak należy zauważyć, że w u.k.u.r., w wyniku jej kolejnych nowelizacji nie zmieniono kryterium obszarowego określającego minimalną normę dla gospodarstwa rodzinnego. Zgodnie z art. 2 pkt 2 oraz art. 5 ust. 1 ustawy jest to obszar nie mniejszy niż 1 ha użytków rolnych. ${ }^{22}$ Dlatego też nie można przeceniać roli Agencji w oddziaływaniu, zwłaszcza na „tworzenie” gospodarstw rodzinnych. Gospodarstwo o powierzchni tylko nieznacznie przekraczającej 1 ha może więc nadal korzystać z przywileju przystąpienia do organizowanego przez Agencję przetargu ograniczonego przy sprzedaży państwowych nieruchomości rolnych.

Potwierdza to np. treść art. 29 ust. 3b pkt 2, 3 czy 5 ustawy z dnia 19.10.1991 r. Wydaje się, że postulat zmiany w zakresie wspomnianego kryterium obszarowego dla gospodarstw rodzinnych jest uzasadniony. Przy tej okazji warto też zauważyć niedokładności legislacyjne zawarte w cyt. art. 29 ust. 3b ustawy z dnia 19.10.1991 r. Zgodnie z treścią wskazanego art. 29 ust. 3b pkt 2 w przetargu mogą uczestniczyć osoby posiadające kwalifikacje rolnicze określone w przepisach o kształtowaniu ustroju rolnego, zamierzające utworzyć gospodarstwo rodzinne w rozumieniu tych przepisów. Natomiast według brzmienia cyt. art. 29 ust. $3 \mathrm{~b}$ pkt $3 \mathrm{w}$ przetargu moga uczestniczyć pracownicy zlikwidowanych państwowych przedsiębiorstw gospodarki rolnej zamierzający utworzyć gospodarstwo rodzinne. ${ }^{23}$ Przepis nie nawiązuje tu do u.k.u.r., co pozwala na dowolność interpretacyjną. Zauważając sygnalizowane tu zmiany obu ustaw - u.k.u.r. oraz ustawy z dnia 19.10.1991 r. uzasadnione jest więc zaznaczenie, że istnieje tu rozbieżność wskazanych celów. Z jednej strony zliberalizowano obrót w świetle u.k.u.r., wskazując, że ze względów strukturalnych szczególnej reglamentacji powinna być poddana tylko część nieruchomości rolnych, z drugiej zaś otwarta jest droga dla stosowania preferencji dla gospodarstw małych, niekorzystnych strukturalnie dla przekształceń rolnictwa. Należy jednak zauważyć, że ANR, zgodnie z ustawą z dnia 19.10.1991 r. realizuje także szereg zadań o charakterze społecznym, na co wskazuje już treść art. 6, a zwłaszcza zadanie określone jako „tworzenie warunków sprzyjających racjonalnemu wykorzystaniu potencjału produkcyjnego Zasobu Własności Rolnej Skarbu Państwa”, czy treść art. 24 ust. 5 pkt 3, a także art. 29 ust. 3c, nawiązujące do preferencji dla osób bezrobotnych. ${ }^{24}$ 
Jak wynika z cytowanych tu niektórych rozwiązań ustawy z dnia 19.10.1991 r. ustawa ta nawiązuje do pojęcia gospodarstwa rodzinnego $\mathrm{z}$ u.k.u.r. traktując ten typ gospodarstw rolnych przede wszystkim jako instrument służący celom przekształceń strukturalnych w rolnictwie. Kierunek jest słuszny i zgodny ze wskazaniem art. 23 konstytucji, aczkolwiek nie całkiem zgodny z celami u.k.u.r. Zwracał już na to uwagę A. Lichorowicz wskazując, że w art. 1 u.k.u.r. określającym cele ustawy pominięto w ogóle problem regulacji statusu gospodarstw rodzinnych. ${ }^{25} \mathrm{Au}-$ tor odnotował jednak pozytywnie sam fakt zdefiniowania przez ustawodawcę pojęcia gospodarstwa rodzinnego, aczkolwiek definicję tę poddał daleko idącej krytyce. Równocześnie Autor nie kwestionował umieszczenia tej definicji w u.k.u.r., zaznaczając jednak, że ze względu na cel ustawy: kształtowanie ustroju rolnego, oczekiwania związane $\mathrm{z}$ definicją gospodarstwa rodzinnego były większe. ${ }^{26} \mathrm{Z}$ poglądem tym należy się zgodzić. Niezależnie od pragmatycznych przesłanek uchwalenia ukur, którymi była przede wszystkim chęć ograniczenia nabywania nieruchomości rolnych przez cudzoziemców, ${ }^{27}$ definicję gospodarstwa rodzinnego wkomponowano w u.k.u.r., wskazując na miejsce gospodarstw rodzinnych w kształtowaniu ustroju rolnego. Gospodarstwo rodzinne, o którym traktuje u.k.u.r. można rozpatrywać w dwóch płaszczyznach. Po pierwsze, wskazano na określoną jednostkę produkcji rolnej, aczkolwiek jak już słusznie odnotowano, przyjęta definicja budzi w tej płaszczyźnie wiele wątpliwości. S. Prutis zauważa np., że należałoby wprowadzić rozwiązania dotyczące organizacji wewnętrznej gospodarstwa rodzinnego, statusu prawnego poszczególnych członków rodziny pracujących w gospodarstwie, zachowania gospodarstwa jako całości gospodarczej zabezpieczającej byt i pracę rodzinie rolniczej. ${ }^{28}$ Po drugie, poprzez przyjęcie rozwiązań wyłączających prawo pierwokupu czy prawo nabycia przez ANR w przypadku obrotu rodzinnego oraz przy nabywaniu nieruchomości rolnych w celu powiększenia gospodarstwa rodzinnego, a także poprzez przyznanie dzierżawcy prawa pierwokupu, gdy nabywana nieruchomość wchodzi w skład gospodarstwa rodzinnego dzierżawcy, wskazywano, że gospodarstwo rodzinne jest w ustroju rolnym wartością prawnie chronioną. Ten rodzaj gospodarstw rolnych jest traktowany bardziej liberalnie.

Szczególne uprzywilejowanie tych gospodarstw w obrocie rolnym wiązać się musi równocześnie z koniecznością spełnienia określonych przesłanek, na które wskazują przepisy art. 5 i 6 ustawy (obszar, osobiste prowadzenie gospodarstwa przez rolnika indywidualnego, kwalifikacje rolnicze). Uzasadnione jest zauważenie, że zakres oddziaływania państwa na gospodarstwa rodzinne ulega poszerzeniu. Zda-

A. Lichorowicz, Instrumenty oddziaływania..., op.cit., s. 405.

Ibidem, s. 405. Inaczej na temat zdefiniowania gospodarstwa rolnego w u.k.u.r. - por. R. Michałowski, Przetarg..., op. cit., s. 239.

Por. na ten temat S. Prutis, Kształtowanie ustroju rolnego - potrzeba nowej regulacji ustawowej, „Studia luridica Agraria" 2005, t. 5, s. 170.

Ibidem, s.183. 
je się to potwierdzać nowelizacja u.k.u.r. z dnia 16.09.2011 r. ${ }^{29}$ Jak wynika z przyjętej wówczas treści art. 6 ust. 1 u.k.u.r. „Za rolnika indywidualnego, o którym mowa w art. 5 ust. 1 pkt 1 uważa się osobę fizyczną będącą właścicielem, użytkownikiem wieczystym, samoistnym posiadaczem lub dzierżawcą nieruchomości rolnych..." Poszerzono więc zakres podmiotów, które uważa się za rolników indywidualnych prowadzących gospodarstwo rodzinne. Przed wspomnianą nowelizacją u.k.u.r. był to tylko właściciel lub dzierżawca nieruchomości rolnych.

5. Poszerzanie kręgu podmiotów prowadzących gospodarstwa rodzinne według u.k.u.r. i odwoływanie się do tej kategorii gospodarstw w innych aktach prawnych może jednocześnie uzasadniać pytanie, dlaczego w tych innych aktach prawnych zawęża się cel przekształceń ustrojowych w rolnictwie akcentując przede wszystkim własnościowy kierunek tych przekształceń. Bardzo wyraźnie podkreślono tę tendencję w ostatniej nowelizacji- ustawy z dnia 19.10.1991 r. Jak wynika z obecnego brzmienia art. 24 ust. 1 pkt 1 tej ustawy „Agencja gospodaruje Zasobem w drodze: 1) w pierwszej kolejności sprzedaży mienia w całości lub jego części na zasadach określonych w rozdziale 6". Sprzedaż, jako prawna forma dysponowania mieniem przez Agencję, już przed wspomnianą nowelizacją była wskazywana na pierwszym miejscu, ale obecnie zaakcentowano silniej preferencje dla tej formy. W tym kontekście zwracają uwagę także te przepisy omawianej nowelizacji, które osłabiają znaczenie dzierżawy jako formy gospodarowania. Przewidziana w nowych przepisach możliwość wyłączenia $\mathrm{z}$ dzierżawy $30 \%$ powierzchni użytków rolnych będących przedmiotem dzierżawy (art. 4 ust. 1 ustawy z dnia 16.09.2011 r.), jak również przeznaczenie wyłączonych użytków rolnych do sprzedaży (art. 4 ust. 10 tej ustawy) są przykładem potwierdzającym przyjętą zasadę, że ustrój rolny będzie opierać się przede wszystkim na gospodarstwach rolnych będących przedmiotem własności. Cytowane tu rozwiązania zdają się być w kolizji ze wskazanym wcześniej poszerzeniem zakresu podmiotowego pojęcia gospodarstwa rodzinnego w u.k.u.r. oraz wyznaczenia Agencji dokonywania przekształceń ustrojowych głównie w oparciu o te gospodarstwa.

6. Zaznaczony kierunek - budowania ustroju rolnego przede wszystkim w oparciu o prawo własności znajduje swoje potwierdzenie także w innych aktach prawnych. Przykładem mogą być rozwiązania przyjmowane w zakresie rent strukturalnych. Jak wynika z $\S 6$ ust. 1 pkt 2 lit. a i b rozporządzenia z dnia 19.06.2007 r. ${ }^{30}$ warunek przekazania gospodarstwa rolnego uważa się za spełniony, jeżeli przekazanie nastąpiło przez ,przeniesienie własności gospodarstwa rolnego”. Poprzednio

30 Rozporządzenie z dnia 19.06.2007 r. w sprawie szczegółowych warunków i trybu przyznawania pomocy finansowej w ramach działania „Renty strukturalne” objętego Programem Rozwoju Obszarów Wiejskich na lata 20072013, (Dz.U. z 2010, nr 131, poz. 886), cyt. dalej jako „rozp. z dnia 19.06.2007 r.” w brzmieniu nadanym mu rozp. z dnia 16.07.2010 r. (Dz.U. Nr 131, poz. 886). 
obowiązujące w tym zakresie rozporządzenie z dnia 30.04.2004 r. ${ }^{31}$ wskazywało, że warunek przekazania gospodarstwa rolnego uważa się za spełniony, jeżeli przekazanie nastąpiło przez przeniesienie własności lub przekazanie wchodzących w skład gospodarstwa rolnego użytków rolnych $\mathrm{w}$ dzierżawę. ${ }^{32}$

Kształtowanie struktury obszarowej gospodarstw rolnych według przepisów o rentach strukturalnych odbywa się $\mathrm{w}$ oderwaniu od pojęcia gospodarstwa rodzinnego. Tylko w odniesieniu do następców, którymi według $§ 2$ pkt 3 rozporządzenia $\mathrm{z}$ dnia 19.06.2007 r. są młodzi rolnicy objęci rozporządzeniem z dnia 17.10.2007 r. ${ }^{33}$ zaznaczono, że chodzi tu o osoby, które po raz pierwszy rozpoczną prowadzenie działalności rolniczej w gospodarstwie rolnym w rozumieniu art. 553 kodeksu cywilnego, jeżeli powierzchnia użytków rolnych w gospodarstwie będzie nie mniejsza, niż średnia powierzchnia gruntów rolnych w gospodarstwie rolnym w kraju oraz nie większa niż 300 ha. Tylko więc do tej kategorii nabywców gospodarstw rolnych na podstawie przepisów o rentach strukturalnych nawiązano do wskazanej w u.k.u.r., jako maksymalnej powierzchni dla gospodarstwa rodzinnego. Dla innych nabywców takiego ograniczenia nie ma. Przekształcenia ustroju rolnego w trybie omawianych przepisów nie muszą się więc nierozłącznie wiązać z koncepcją gospodarstwa rodzinnego.

7. Z punktu widzenia oddziaływania na przekształcenia strukturalne $\mathrm{w}$ rolnictwie istotne znaczenie mają także rozwiązania przyjmowane $\mathrm{w}$ związku $\mathrm{z}$ działalnością Agencji Restrukturyzacji i Modernizacji Rolnictwa. Już w ustawie stanowiącej podstawę działania tej Agencji ${ }^{34}$ wskazano, że do zadań tej Agencji należy m.in. wspieranie poprawy struktury agrarnej, w tym zwłaszcza tworzenia i powiększania gospodarstw rodzinnych w rozumieniu przepisów o kształtowaniu ustroju rolnego (art. 4 ust. 1 pkt 3). Jak wynika z treści art. 4 ust. 3 wskazanej ustawy, Agencja realizuje zadanie w zakresie dotyczącym tworzenia powiększania gospodarstw rodzinnych w szczególności przez dopłatę do odsetek od kredytów bankowych lub częściową spłatę kapitału kredytu udzielonego na zakup nieruchomości rolnych, które utworzą takie gospodarstwo albo wejdą w jego skład, z tym że kwota kredytu nie może przekraczać $90 \%$ wartości nabywanej nieruchomości, a okres spłaty kredytu nie może przekraczać 20 lat.

31 Rozporządzenie z dnia 30.04.2004 r. w sprawie szczegółowych warunków i trybu udzielania pomocy finansowej na uzyskiwanie rent strukturalnych objętej planem rozwoju obszarów wiejskich (Dz.U. Nr 114, poz.1191 z późn. zm.).

$\S 6$ ust. 1 pkt 2 lit. a-c. Por. na ten temat E. Kremer, Zasady nabywania rent strukturalnych - zagadnienia wybrane, „Rejent” 2009, nr 3, s. 22 oraz K. Stefańska, Sytuacja prawna młodych rolników w procesie zmiany generacji w rolnictwie, „Studia luridica Agraria” 2011, t. 9, s. 179.

Rozporządzenie z dnia 17.10.2007 r. w sprawie szczegółowych warunków i trybu przyznawania pomocy finansowej w ramach działania, „Ułatwianie startu młodym rolnikom” objętego Programem Rozwoju Obszarów Wiejskich na lata 2007-2013, (Dz.U. Nr 200, poz. 1443 z późn. zm., cyt. dalej jako „rozp. z dnia 17.10.2007 r.”). Agencja cyt. dalej jako ARiMR. 
Uszczegółowienie ustawowo określonych zadań ARiMR zawiera rozporządzenie wykonawcze, do cyt. ustawy. ${ }^{35} \mathrm{~W}$ zakresie realizacji zadania dotyczącego wspierania gospodarstw rodzinnych zauważyć można, że zgodnie z ustawową regulacją wskazaną w art. 4 ust. 1 pkt 3 cyt. już ustawy, gospodarstwa te stanowią tylko jeden z elementów oddziaływania przez ARiMR. Zgodnie bowiem z treścią $§ 10$ ust. 3 pomoc finansowa udzielana przez Agencję może być zwiększona w przypadku zakupu użytków rolnych mającego na celu: a) powiększenie gospodarstwa rolnego, b) utworzenie nowego gospodarstwa rolnego o powierzchni nie mniejszej od średniej powierzchni użytków rolnych w gospodarstwach rolnych w danym województwie, c) utworzenie gospodarstwa rodzinnego w rozumieniu przepisów o kształtowaniu ustroju rolnego lub powiększenie takiego gospodarstwa, d) utworzenie lub urządzenie gospodarstwa rolnego przez osoby, które nie ukończyły 40. roku życia. Gospodarstwa rodzinne w rozumieniu u.k.u.r. są więc jedną z kategorii gospodarstw wspieranych przez ARiMR. Należy jednak zauważyć, że wspieranie zakupu użytków rolnych na powiększenie gospodarstwa rolnego ograniczone jest w dalszych przepisach omawianego rozporządzenia. Zgodnie bowiem z treścią $\S 10$ ust. 4 pkt 2 lit. a zwiększone dopłaty do kredytów bankowych udzielanych m.in. na zakup użytków rolnych nie przysługują w odniesieniu do tej części nabywanych użytków rolnych, która spowoduje powiększenie powierzchni gospodarstwa rolnego lub gospodarstw rolnych będących w posiadaniu tego samego producenta rolnego do ponad 300 ha użytków rolnych.

Gospodarstwa rodzinne w świetle omawianych przepisów są jednym z instrumentów wykorzystywanych dla poprawy struktury obszarowej, ale równocześnie poprzez wyraźnie zaznaczone już w ustawie preferencje finansowe przy tworzeniu i powiększaniu tych gospodarstw (cyt. art. 4 ust. 3) - mają również pozycję uprzywilejowaną wśród innych gospodarstw, które wspiera ARiMR. Odwoływanie się $\mathrm{w}$ tych przepisach do pojęcia gospodarstwa rodzinnego w rozumieniu u.k.u.r. pociąga za sobą wszystkie konsekwencje prawnego określenia tego gospodarstwa, a więc również zakresu podmiotowego tego pojęcia. Chodzi oczywiście o osoby prowadzące gospodarstwo rolne i posiadające kwalifikacje rolnicze. W przypadku innych gospodarstw - nie muszą one spełniać wskazanych kryteriów, a także korzystają z podobnego wsparcia finansowego, na które wskazuje rozporządzenie wykonawcze do ustawy. Omawiane rozwiązania budzą jednak także inne wątpliwości. W u.k.u.r., jak już była o tym mowa, poszerzono zakres podmiotowy pojęcia gospodarstwa rodzinnego, natomiast według omawianych przepisów wspiera się finansowo tylko zakup użytków rolnych mający na celu utworzenie lub powiększenie gospodarstwa rodzinnego. 
Ponadto uzasadnione może być również pytanie, dlaczego zwiększone dopłaty nie przysługują do kredytów bankowych udzielanych na zakup użytków rolnych, jeżeli umowa jest zawarta między rolnikiem a następcą na podstawie przepisów o ubezpieczeniu społecznym rolników, jeżeli następca jest zstępnym, przysposobionym albo pasierbem rolnika ( $\$ 10$ ust. 4 pkt 1 lit. b). Zestawienie cyt. rozwiązania z przyznawaną obrotowi rodzinnemu ochroną według u.k.u.r. może, jak sądzę, budzić pewne wątpliwości. Co do zasady, treść cyt. przepisu może być zrozumiała. Chodziło oczywiście o zapobieżenie wykorzystywaniu pomocy finansowej, zawieraniu fikcyjnych umów, by skorzystać ze świadczonych form pomocy, ale w odniesieniu do gospodarstw rodzinnych nie wydaje się, by było to rozwiązanie słuszne. Wynika ono zapewne $\mathrm{z}$ tego, że gospodarstwa rodzinne potraktowano w tym zakresie tak jak wszystkie inne gospodarstwa, nie czyniąc tu żadnego zróżnicowania. Wydaje się, że gospodarstwa rodzinne powinny korzystać w tym względzie ze szczególnego wsparcia. Odpowiadałoby to ogólnemu konstytucyjnemu założeniu, że gospodarstwa rodzinne są podstawową formą gospodarowania w rolnictwie. We wszystkich rozwiązaniach prawnych, które nawiązując do gospodarstw rodzinnych powinny być stosowane te same zasady ich ochrony. Natomiast, jak wykazują cyt. w tych rozważaniach przykłady, regulacje prawne nie są w tym zakresie spójne.

Ten brak spójności w odniesieniu do określenia miejsca gospodarstw rodzinnych wśród innych form gospodarowania w rolnictwie dobrze ilustrują także uwagi A. Lichorowicza zgłaszane w związku z omawianą już wcześniej w tym opracowaniu nowelizacją ustawy z dnia 19.10.1991 r. ${ }^{36}$ Autor, oceniając krytycznie przyjęte rozwiązania w noweli do ustawy zauważa, że niektóre jej postanowienia są niekonsekwentne z punktu widzenia celu tej noweli, a mianowicie wzmocnienia sektora gospodarstw rodzinnych w Polsce. ${ }^{37}$ Ten brak konsekwencji Autor ilustruje opisem sytuacji, kiedy rolnik zgodzi się przekazać z powrotem ANR 30\% dzierżawionych gruntów z dużego, np. 800 ha, gospodarstwa. W takim przypadku może wykupić na własność pozostałe 70\%. Autor wskazuje, że ,za cenę odzyskania szybko 300 ha ANR godzi się na powstanie własnościowego 500-hektarowego gospodarstwa, które trudno nazwać gospodarstwem rodzinnym". ${ }^{38}$ W konkluzji swoich rozważań autor stwierdza m.in., że te oraz inne niekonsekwencje omawianej ustawy są zwłaszcza wynikiem nagłej zmiany polityki rolnej, obawą konkurencji UE, ale nie może to prowadzić do stosowania skrótów i nowelizacji, które podważają podstawowe, prawnie chronione zasady. ${ }^{39}$

36 Por. przypis 15.

37 A. Lichorowicz, Nowy etap rozwoju prawnej regulacji dzierżawy gruntów państwowych, (w:) Z zagadnień prawa rolnego, cywilnego i samorządu terytorialnego. Księga Jubileuszowa Profesora Stanisława Prutisa, Białystok 2012, s. 213.

$38 \quad$ Ibidem, s. 213.

$39 \quad$ Ibidem, s. 214. 
8. Uwagi A. Lichorowicza w pełni należy podzielić. Potwierdzają one także to, co już zostało przedstawione w niniejszym opracowaniu. Miejsce gospodarstwa rodzinnego w prawnej regulacji obrotu rolnego nie jest jeszcze wyraźnie zaznaczone. Na podstawie przyjętego do analizy materiału normatywnego można jedynie zauważyć. tendencję budowania modelu gospodarstwa rolnego w oparciu o kryterium własności. Potwierdzają to przypomniane już wcześniej regulacje dotyczące gospodarowania nieruchomościami rolnymi Skarbu Państwa, rent strukturalnych, czy przyznawania środków finansowych przez ARiMR. W rozwiązaniach tych nawiązuje się do pojęcia rodzinnego gospodarstwa rolnego według u.k.u.r., ale równocześnie z tych samych preferencji, z których mogą korzystać wspomniane gospodarstwa, mogą też korzystać inne, określone jako rodzinne, ale już bez zaznaczenia, że są to gospodarstwa rodzinne w rozumieniu u.k.u.r. Tak ma miejsce np. w omawianych już przepisach zawartych w ustawie z dnia 19.10.1991 r., czy w przepisach dotyczących zadań ARiMR. Wspomniane przepisy nie wyznaczają gospodarstwom rodzinnym w rozumieniu u.k.u.r. jakiejś szczególnej roli w przekształceniach ustrojowych rolnictwa, nie traktują tych gospodarstw jako wartości szczególnie chronionych. Gospodarstwa te są traktowane jako instrument wykorzystywany przy zmianach ustrojowych rolnictwa. Należy także zauważyć, że zmiany w legalnej definicji gospodarstwa rodzinnego przyjęte w wyniku ostatniej, wskazywanej już w tym opracowaniu nowelizacji u.k.u.r., poszerzającej zwłaszcza zakres podmiotowy pojęcia nie znalazły swojego potwierdzenia $\mathrm{w}$ innych aktach prawnych, które przede wszystkim odwołują się do tego pojęcia w jego własnościowym aspekcie, podważając tym samym zasadność prowadzenia działalności rolniczej w gospodarstwach będących np. przedmiotem dzierżawy. Ponadto, nie zmieniając minimalnej normy obszarowej dla pojęcia gospodarstwa rolnego, daje się zupełnie małym gospodarstwom określone przywileje, wskazując równocześnie, że tylko te, których powierzchnia jest większa niż 5 ha, powinny być w sferze zainteresowania Państwa, a w ten sposób przejmowany obszar nieruchomości rolnych mógłby być przeznaczany na cele restrukturyzacji rolnictwa.

Nie wracając już do wszystkich szczegółowych uwag, uzasadniony wydaje się postulat wyraźnego określenia miejsca gospodarstw rodzinnych w obrocie rolnym, którego rozwiązania są szczególnie istotne dla przekształceń strukturalnych w rolnictwie. Przede wszystkim należałoby zmierzać do eliminacji szeregu niekonsekwencji, które obecnie mają miejsce, gdy chodzi o określenie roli i miejsca gospodarstw rodzinnych w prawnej regulacji obrotu. Jeśli w tej regulacji nawiązuje się do pojęcia rodzinnego gospodarstwa rolnego zawartego w u.k.u.r., to pojęcie to, z wszystkimi konsekwencjami, powinno znajdować wyraz także w innych, poza u.k.u.r., aktach prawnych. Obecny stan prawny jest w tym zakresie bardzo niezadawalający. 
THE PLACE OF A FAMILY FARM IN AGRICULTURAL TRADE (SELECTED ISSUES)

Key words: family farm, agricultural system, agriculture.

To the concept of a family farm, constituting under article 23 of the Constitution, the basis of the agricultural system, the legislator refers in a number of legal acts. Among these laws are those that are of particular importance for the structural transformation of agriculture, and also concern trading of agricultural land. In the essay it was attempted to determine the place of a family farm in this legal regulation. Analysis carried out in this field shows there is a lot of inconsistency in enacted in this area legal regulations. The legislator refers primarily to proprietary market, builds a model of agricultural holding mainly on property law, while in the Act on forming rural system indicates that the family farm is a farm run by, for example, the leaseholder. Family farm is treated rather instrumentally to agricultural trade, rather than as a value that should be subject to special protection. 